long before actual flight in an aeroplane had become possible. So early as 1901 he delivered a lecture at the Royal Institution in which he affirmed his belief in the possibility of artificial flight. Two years later he realised the necessity of making an attempt to ensure the longitudinal stability of flying machines, and in January 1904 he published, in collaboration with Mr. W. S. Williams, the epoch-making paper on the longitudinal stability of aerial gliders, in which he introduced the important conception of resistance derivatives, deduced the biquadratic equation which governs stability, and applied Routh's discriminant to the obtaining of the conditions of stability.

This mathematical theory gained the approval neither of mathematicians nor of those brave pioneers who demonstrated the practicability of aeroplane flight in the first decade of the present century. But Bryan persevered in his somewhat lonely work, and seven years later he published his "Stability in Aviation," a book that may now be reckoned as a classic in aeroplane theory. Meanwhile the Advisory Committee for Aeronautics had been established, and a department of aeronautics set up at the National Physical Laboratory. Bairstow developed practical methods for finding the numerical values of the resistance derivatives by means of the aerodynamic balance and wind channel, and very soon Bryan's theory of stability became an integral part of all aeroplane design. His triumph was complete when in 1914 he was awarded the gold medal of the (now) Royal Aeronautical Society. It is difficult to over-estimate the service thus rendered to aviation by the theoretical mathematician.

Bryan continued to interest himself in the rigid dynamics of aviation, and inspired the researches of many workers. From 1917 until 1920 he worked with the advantage of a special grant, which enabled him to set himself free from teaching duties for a part of the time. He spent several months at Bristol in collaboration with the present writer and Mr. D. Williams, elaborating the theory of canonical forms for dealing with the general motion of an aeroplane.

In addition to the honours already indicated, Bryan obtained the fellowship of the Royal Society in 1895, and was elected honorary fellow of Peterhouse in 1915. He served as president of the Mathematical Association and of the Institution of Aeronautical Engineers. He was an honorary member of the Calcutta Mathematical Society. Reference must also be made to the series of text-books written by Bryan on mathematics, mechanics, and astronomy for the University Tutorial Press.

Bryan married Miss Mabel Williams in 1906. Mrs. Bryan is now living at the villa near Bordighera in Italy, where Prof. and Mrs. Bryan made their home on Bryan's retirement in 1926. Their only daughter is now a student at Cambridge. A fortnight before his death, Bryan met many friends at the International Mathematical Congress at Bologna.

In the words of an old friend of Prof. Bryan, Dr. F. J. Allen of Cambridge, Bryan was distinguished by "straightforwardness of character and generosity ; by an ardent love of the beautiful in landscape, and for living things such as plants and insects which are so bound up therewith ; by his great love of music, and the large part of his mind which it occupied." Bryan devoted much thought and experiment to the working of " player " pianos, and invented an apparatus for accentuating any particular note or melodic passage. His two years of retirement at Bordighera were made happy by friendly intercourse with the Italian peasants, whose language he spoke so well, and 'II Professore ' was known and loved in many a mountain village far off the beaten track of the ordinary tourist.

S. Brodetsky.

\section{Sir Alexander Kennedy, F.R.S}

A NOTABLE figure in the engineering and scientific world is removed by the death of Sir Alexander B. W. Kennedy, F.R.S., in his eighty-second year. Born in London in 1847, the son of the Rev. John Kennedy, D.D., and Helen Stodart, sister of Prof. John Stuart Blackie, Kennedy received his early education at the City of London School and the School of Mines, Jermyn Street. In those early days there were no means of further education in his chosen profession of engineering, except by its actual practice, and for the next few years Kennedy was laying the foundations of his ultimate eminence as an engineer in the workshops and drawing offices of well-known firms of marine engineers in London and the north. In a surprisingly short time he was a leading draughtsman and an authority on the design and construction of the machinery of ships, and evincing thus early the keen judgment and sagacity in practical affairs which were so marked a feature of his character.

At the early age of twenty-seven, a turning-point in Kennedy's career was reached when he applied for, and obtained, the professorship of engineering at University College, London. It was a momentous step for the electors and himself, which was amply justified by events, for Kennedy proved to be an ideal professor as well as a notable pioneer in education and applied science. His outstanding educational achievement was his invention of the engineering laboratory as an essential part of a university course, a system which has spread all over the world and has proved so potent an influence for good in engineering education.

In his scientific work Kennedy was much attracted by the kinematic analysis of Realeaux, which he brought into prominence here by his lectures and his well-known text-book on "The Mechanics of Machinery." On the experimental side he became an authority in many branches of applied science, such as the scientific testing of boilers and steam engines, and also by researches on the properties of engineering materials and structures, for which he designed an autographic stress-strain recorder of great sensitiveness. As time went on, his advice and assistance on engineering matters were so much sought after that the strain became too great and he resigned his professorship in 1889 and went into practice as a

No. 3083, VoL. 122] 
consulting engineer, although he remained in intimate touch with University College to the end of his life, and his name is permanently associated. with his old chair there.

It may seem somewhat surprising that Kennedy's activities soon took a new turn into electrical engineering, for which there seemed to be no warrant from his previous training and experience, but possibly this can be explained by the fact that this branch was in its infancy and that what it then needed more than anything else was the mechanical engineering ability which Kennedy possessed in so remarkable a degree, for the major difficulties of that period were not so much electrical as mechanical.

It would take too long to enumerate the great electrical engineering enterprises with which Kennedy was associated: railways, tramways, power houses, and the like. There was one common feature in all this work, that Kennedy's advice was always of the best and his undertakings successful. Naturally, his share of honours was great. $\mathrm{He}$ became a fellow of the Royal Society in 1887, president of the Institution of Mechanical Engineers in 1894, and president of the Institution of Civil Engineers in 1906, a year after receiving the honour of knighthood for eminent services in naval matters connected with boilers and machinery. $\mathrm{He}$ was also the recipient of many honorary degrees and distinctions.

All this, however, doess not really give an adequate idea of Kennedy's many-sided character, for he possessed by heredity and training that love of knowledge, eulture, and adventure which led him into many fields: music, archæology, photography, and mountain climbing were some of his recreations, and he excelled in a knowledge of them all. He will be much missed by a large circle of friends, among whom will be numbered all his old students, who derived so much inspiration from his teaching and example.

\section{Dr. Theodor Paul.}

WE are indebted to the Chemiker-Zeitung for the following details of the life of Prof. Theodor Paul, of Munich, one of the best known authorities on pharmaceutical chemistry, who died on Sept. 30, after a long illness.

Born in 1862 at Lorenzkirch on the Elbe, Paul took up the study of pharmacy on leaving school, and after some years' experience as an assistant he entered the University of Leipzig. After obtaining a qualification in pharmacy he took up the study of chemistry under Prof. E. Beckmann, and graduated in 1891. After graduation Paul came under the influence of Prof. Wilhelm Ostwald, who aroused in him a keen interest in physical chemistry, the effects of which were noticeable in all his later work. After serving as assistant to Ostwald for six years he was appointed assistant to Beckmann in the newly established laboratory of applied chemistry, and in 1898 he followed Buchner as extra-ordinary professor of analytical and pharmaceutical chemistry at the University of Tübingen. Meanwhile he had commenced the study of medicine, and while still at Tübingen he graduated a second time at Leipzig, this time in the faculty of medicine. In 1902 he was appointed director of the research department of the Imperial Public Health Office in Berlin, where he remained until 1905, when he followed Hilger as professor of pharmaceutical and applied chemistry at the University of Munich.

Paul took a prominent part in the preparation of the fifth and sixth editions of the "Deutsches Arzneibuch," and he published numerous papers on the investigation of food and drugs. In 1921 he accepted an invitation to deliver a course of lectures at the University of Madrid. He filled many important offices, and at the time of his death was director of the German research institute for the chemistry of foodstuffs and a member of the Bavarian Academy of Science.

Mr. Walter BrocketT, head assistant in the Zoological Laboratory, Cambridge, died on Nov. 11. He had been in the same employment for forty-eight years, at first as a boy under $\mathrm{F}$. M. Balfour and later under Adam Sedgwick and the present writer. $\mathrm{He}$ was an expert at section cutting, at first single sections and then as an operator of the original ribbon machines, which by his criticisms he helped to perfect. A part of his business was to mark off students at lectures and practicals, and a rough calculation shows that more than 7000 names are recorded in his books; he seldom forgot the name of anyone therein, and he generally would recall their peculiarities and athletic distinctions. A photograph of the annual laboratory cricket match, 'Assistants v. Staff,' shows him as captain seated alongside Dr. Gaskell, who had Sir Michael Foster, Sir Francis Darwin, Dr. W. Bateson, Sir Morley Fletcher, Prof. Barclay Smith, Mr. Brindley, Mr. Warburton, and the writer in his team. He regarded Cambridge as his University, the Laboratory as his department, and its graduates as his students, and he was proud of them. He was noted in Cambridge for his successful management and training of laboratory assistants, most of whom migrated to other universities. His affectionate and loyal relations with professor and staff makes their sense of loss very deep and personal. He leaves a fine example of whole-hearted loyalty and devotion. J. S. G.

WE regret to announce the following deaths:

Dr. John A. Bownocker, chairman of the department of geology at the Ohio State University since 1916 and State geologist of Ohio since 1906, who was interested chiefly in the economic geology of the region, on Oct. 20, aged sixty-three years.

Sir Hector Cameron, C.B.E., emeritus professor of clinical surgery in the University of Glasgow, a pupil and assistant of Lister, on Nov. 25, aged eighty-five years.

Dr. E. A. Schwarz, of the Bureau of Entomology of the U.S. Department of Agriculture, who was distinguished particularly for his knowledge of the Coleoptera, on Oct. 15, aged eighty-four years.

No. 3083, Vor. 122] 